\title{
CHALLENGES TO THE BRAZILIAN AGROFOOD INDUSTRY IN THE GLOBAL MARKET*
}

\author{
Nilson M. de Paula**
}

\section{INTRODUCTION}

International economics literature has recently devoted great attention to the complex process of globalization. Whatever the course of the discussion, an important question dealt with by different authors is that of how the economies are facing the challenges posed by a more internationally competitive environment. In other words, competitiveness has become a key question in the international economic relations of the last decade, when most countries started opening up their economies to the external flows of trade and investment. ${ }^{1}$

Despite different concepts, competitiveness is in the end based on the ability of each industry to be in line with the technological, efficiency and organizational patterns prevailing in the markets where it is competing. Industrial competitiveness thus indicates the ability of entrepreneurs to produce goods more attractive in the eyes of consumers. Moreover, attention should be paid to overall economic changes caused by trade and industrial policies of countries taken individually and also belonging to common trade areas.

On the other hand, for Krugman (1997) competitiveness is a concept not to be used for a country as a whole, on the basis that competitive

*I am grateful to Capes for the financial support given to the post doctorate project develop in 1998/99 at the Department of Agricultural and Food Economics / Univerty of Reading, UK.

**Lecturer at the Department of Economics / Universidade Federal do Paraná.

1 It must be pointed out that this process is still affecting a small proportion of countries and consequently their population. Many developing and poor countries have either not been able to exploit their comparative advantages or have not succeeded in participating in this overall transformation. 
firms can produce spillovers to the whole of the economy, unless market failures predominate. The more insignificant these failures are, the more widespread the beneficiaries will be. This in an approach opposed to the argument that combines the challenges of the market with the standard of living of the entire population (REINERT, 1995). From this perspective, this discussion is not to be addressed in the light of market failures, since these are structural elements of the economic dynamics.

In the last decade, the terms of competitiveness have changed with the changing nature of the world economy, which can be epitomized by three major developments. Firstly, there has been growing liberalization of trade and a greater integration between national economies in regional markets. Secondly, an increase in foreign direct investment as part of the competitive strategies of the firms has been a key element in transforming national economies. Thirdly, the role of national governments has changed considerably, both domestically and as part of a worldwide range of new institutional arrangement.

Within this context firms have come under pressure to innovate and decrease prices as vital means for competition. Paraphrasing Ostry (1997), firms are stimulated to design new strategies to improve access to markets by capturing the competitive advantages of national economies, increasing economies of scale and scope, keeping pace with consumer behaviour, and reaping the rewards of local investments in $\mathrm{R} \& \mathrm{D}$.

Following this caveat, two aspects should be taken into account in an analysis of specific sectors of activity. Firstly, their features vary widely according to their market segments and respective demand, market structure and the behaviour of competitors, etc. Secondly, a distinction should be made between countries in terms of consumption standard, the existing infrastructure, the opportunities for investment, and most of all the degree of industrialization.

After the opening up of the Brazilian economy to foreign trade and investment in 1990, and the corresponding competitive strategies adopted both by the government and firms, a new question related to competitiveness came to the fore. The transition towards an integrated world economy has led to a fiercer competition for incumbent firms, as new entrants, mainly multinationals have increased direct investment and have also given priority to the exporting of processed and differentiated products, rather than of homogenous commodities. The new area of competition in the global market is thus defined by the technology used for innovation of production processes and in the creation of new products, particularly when a converging consumption standard worldwide is intensifying. However, 
potential conflicts arise as local and national business face foreign competition, thereby demanding adequate government policies either to protect certain sectors by means of trade policies or to enable others to be competitive as a result of industrial or competitive policies.

The analysis to be carried out here concentrates mainly on the trends of international trade and foreign direct investment in the food sector, and focuses on Brazil during the 1990s. The core of this analysis indicates the challenges facing Brazilian food industry in the international market when differentiated products increasingly dominate trade relations. Furthermore, this analysis explores the extent to which foreign direct investment can change the conditions under which a country can boost competitiveness in such a market, as can be seen in section 2. Finally it will be argued that the process of opening-up the Brazilian economy in the 1990s has so far consolidated the country's position as a commodity exporter in an international market where processed and differentiated products have been predominant.

\section{INTERNATIONAL TRADE AND THE AGROINDUSTRY}

Trade has been historically associated with the population welfare, economic growth, and increasing technological innovation. The underlying idea is that a wider market is a precondition for increasing the economy of scale and scope and for driving industry to better performance as a way of increasing returns in a more competitive market. Trade liberalization has throughout the years been regarded as a target to be achieved by world economies, according to the directives put forward by international institutions. ${ }^{2}$ This has, however, become a daunting challenge, given the raising of tariff and non tariff barriers, as happened in the 1970s and 1980s, when the later occurred particularly among the developed countries. Recent disputes between the USA and the EU amid a growing concern over prospects of a slowdown in the world economy and also excessive trade deficits in the major industrialized countries, have made the prospects of market liberalization look grim again.

2 Irrespective of the fact that trade is commodity or differentiated product based, some analysis, particularly by international institutions, such as the World Bank and individual authors (VALDES,1987; JOSLING,1995) have highlighted the progress shown by the free market. There is thus an overall belief that the more open the market is the more widespread its gains are. 
Nonetheless, in a historical perspective, the arguments for free trade have changed from a mere condemnation of protectionism to a criticism of state intervention through different types of economic policies. From this perspective, even strategic policies meant to protect infant industries or to drive backward industries to a competitive position have been condemned. Likewise, import-substitution models adopted by developing countries mainly in the 1960s as a strategy to stimulate local industrialization have been considered historical mistakes from the liberalization stand point.

In recent years, when the Uruguay Round of GATT was concluded, there seemed to be a reversal in the previous trend. Between 1994 and 1997, world output increased by an average of 3,9\%, whereas world trade volume grew by $8,7 \%$ (IMF, 1997/98). This increase on trade is however restricted to the expansion of barter which is believed to have generated gains for all participants, provided they are prepared to outstrip trade barriers and face foreign competition. On the other hand this assessment is deeprooted in the assumptions of comparative advantages and specialization in the activities that are performed better by one country, relative to others.

It is largely due to such specialization and international trade that, on average, the level of consumption (real incomes) has increased by about four times over the last eight decades (HOEKMAN; KOSTECKI, 1996, p. 21)

The expansion of trade, seen from this perspective, has concealed a variety of aspects, which have made the international market very uneven and complex. It is one thing to recognize the importance of the free market, and another one to associate growth of trade with perfect competition and specialization, which means the absence of economy of scale, product differentiation, oligopolist competition and so on. The means whereby countries and firms become involved in the international trade, and the results accomplished differ across the production structure. In other words, the ability to take part in the international market has increasingly been associated with factors other than natural resources endowments, raw material supply, cost of labour force, etc. In fact, if the market share of a country is small, this might be the result of a shortcoming in creating competitive advantages by means of industrial policies and the exploitation of economy of scale by individual firms, not to mention overall institutional arrangements tuned to competitiveness requirements.

The process leading to trade liberalization cannot thus be associated with the elimination of barriers as a sole precondition for promoting 
exchange of goods and services between nations. Despite the arguments according to which trade liberalization may contribute to the increasing of the volume of commerce and unleashing a search for new opportunities in a wider market, it also gives rise to problems of adjustment among producers in its path. Again, for those with strong beliefs in free competition this is a matter for the market forces to settle. In reality, the basic assumption of this argument is that of comparative advantages and specialization. That is countries import certain goods because of comparative disadvantages, and others export them because of their comparative advantages. Such an assumption does not hold in the light of recent changes in the world economy. As Feketekuty (1992) argues, global goods and services are increasingly traded internationally without a particular national origin. Moreover, countries export and import similar products as competition spreads over national boundaries and trade becomes more significantly of an intra-industry nature. In other words, the front line of international trade is moving away from inter-industry relations, therefore leaving behind static specialization based on inherited factors. On the other hand, as has been stressed in the literature, intra-industry trade tends to be more intensive between countries according to the similarities in terms of economy of scale and scope and technological advances; to the similarities in the standard of consumption; and the involvement in regional markets.

Therefore, to understand trade, two main aspects underlying it must be taken into account. Firstly, trade is not only the expression of comparative advantages but is also of created competitive advantages. Secondly, trade rather than being a result of specialization, has been marked by intra-industry transactions in which economies of scale innovation and product differentiation play a decisive role. Despite arguments based on perfect competition, according to which the larger the number of firms in an industry, the greater the intra-industry trade (IIT), there is a strong association between IIT and an oligopolist market structure. This is so simply because the larger firms are able to achieve higher levels of efficiency more easily. However, it is widely held that, in the light of a higher openness of national economies to foreign trade and investment flows, incumbent firms are more likely to face competition if they are involved in IIT, which is itself conducive to higher levels of competitiveness.

Besides an increasing openness of most countries to the world market, increasing trade flow has also been underpinned by structural changes in the production system. In other words greater trade implies greater competition "and therefore pressures to innovate and enhance productive 
efficiency, while at the same time allowing technological upgrading" (HOEKAMN; KOSTECKI, 1996, p. 10).

In the agrofood system, trade has changed significantly from the previous North/South relations, in which the supply of raw material by developing countries was the main feature. Despite the fact that bulky commodity has been the dominant element of trade it is important to stress the changes in the composition of food products traded in recent years. Between 1972 and 1993 the value of trade in manufactured products increased by $574 \%$ compared to $355 \%$ for bulk commodity. Also, in 1993, processed food products accounted for $67 \%$ of the world trade in the food sector (HENDERSON et al. 1998). International food trade has thus become much more complex and as such has required an explanation based on aspects other than resource endowments and factor. Basically, the fact that trade is becoming intra-industry revolves around a dynamics in production structures where not only economies of scale and scope, but also product differentiation and process innovation coupled with new marketing strategies are at the core of competitive advantages

Another remarkable characteristic of international food trade is the level of concentration among both firms and countries. Of the fifty largest food-processing firms, the largest ten were responsible for $44 \%$ of the processed food trade. As for countries, only twenty-four were responsible for $68 \%$ of the manufactured food trade in 1962 and $80 \%$ in 1990. France, the Netherlands, the United States, Germany and the United Kingdom accounted for $38,2 \%$ of the world manufactured food exports. Of the imports, Japan, Germany, the USA, France and the UK traded 52,7\% of the total in 1990 (HENDERSON et al. 1998). Indeed, the international market in recent years has maintained an uneven distribution between blocs of nations. In general, most of the trade has been conducted by the US, the EU and Japan. Less developed and developing countries have been responsible for a smaller amount of trade in the agroindustrial sector, most of trade consisting of natural or semi-processed commodities with a low level of differentiation. Additionally, most of the trade has been intra-regional, North America and Western Europe being the most important trade areas, which mirrors the concentration of food industries in these countries.

Based on this evidence of concentration in the trade of manufactured food, it has become important to investigate the prospects for developing countries in such an environment. As agriculture-based and processed agricultural commodities account for a significant group of these countries' exports, they tend to bear the brunt of recent slump in prices for many commodities in world market. Moreover, the challenges for these 
countries to implement industrial policies have tended to become more difficult the closer the prescriptions of comparative advantages embodied in most of the free trade based recommendations are followed. As a corollary the opportunities for increasing competitiveness in many countries tend to decrease significantly at a rate similar to the increase in trade deficit. The strategy adopted by many LCD's and developing countries to a great extent vindicates this concern, especially that related to overvaluation in the exchange rate and to a reform of State with major impacts on the ability of many governments to implement industrial and agricultural policies.

\section{FOREIGN DIRECT INVESTMENT IN THE AGROINDUSTRY}

Another central feature of globalization in recent years is the increase of foreign direct investment. Growth of intra-industry trade has strongly influenced the position of FDI as complementary to rather than substitute for trade. Moreover, expansion of FDI has been the driving force of a more integrated economy and as such led trade to increase according to the organization of production in different. On the other hand, a close competition in the home countries coupled with the attractiveness created by economic policies in host countries underpins the flow of capital towards new markets. This expansion of investment has taken various formats and has strongly determined the emergence of a global pattern of production and consumption. FDI is in the end an expression of an accelerated internationalization of production by means of an increased mobility of capital and of knowledge and technology (STRANGE, 1997).

From a liberal perspective, any country, regardless of its level of development, should be open to inbound investment as an overall strategy to step up its competitiveness in the world market. The question here then relates to the attractiveness of host countries in terms of new opportunities and liberal institutional arrangements (BANNISTER, et al. 1994). However, this falls short of explaining the actual dynamics behind foreign investment, as liberalization of domestic markets are usually restricted to two basic aspects: reduction of State influence in the economy, and domestic market strengthening. Too little attention is paid to the requirement of an R\&D system and to a socially extending access to education by means of State policies.

Therefore, the liberalization agenda does not fully meet the challenge posed by recent trends in international trade. The new competitive advantages required to compete in the world market are far beyond the 
scope of factor endowments. In fact the conditions for successful competition are related to the implementation of National Systems of Innovation to be implemented by industrial policies. On the other hand, the process of Schumpeterian "creative destruction" is bound to force small national firms out of business, and thus increase the social cost of competition. As a result, a safety net is required to minimize such a trend, which something free market alone cannot provide.

Following a liberal point of view a full openness of economies can increase the population welfare because competition is able to lead national firms to increase efficiency and consumers can benefit from better prices and a wider range of supply. Therefore, no room would be allowed for industrial policies aiming at a development based on national firms, since the issue would be how to sustain competitiveness, regardless of the entrepreneurs' origins. As for the outward investments the notion of losing production capacity has nowadays given way to the view that in a global economy, such investments are in a position to turn domestic industry into global competitors (LIPSEY, 1997).

However, concern grows in relation to the inevitable adjustment process after national firms are brought into open competition, bearing in mind the resulting foreclosures and desinvestment by national firms, resulting in higher unemployment, specially in less developed countries. The redeployment of resources is not a straightforward process to be carried out by the invisible hands of the market. This question cannot therefore be treated in the framework of perfect competition, mainly when technological innovation, product differentiation and economy of scale are at stake. The fact that small firms cannot compete should not be seen as overall market failures, but as a result of how real competition works.

Following the design of a new set of strategies, companies undertaking foreign investment have plunged into a competing field where concentration, through mergers and acquisitions, has been a persistent rule of the game, strengthening the position of Multinational Enterprises (MNEs). Again, although the degree of attractiveness to inbound FDI varies among the economies according to different factors, the question to be addressed in discussing food industry should be focused on two aspects. Firstly the impact of FDI for improving the host country's competitiveness in upgrading the existing ability to explore potential resources. Secondly, the extent to which the relationship between new entrant companies and national governments is conducive to promoting change in the national economic development, and also in leading industrial sectors to compete in the international market. In other words, following the discussion on the growth 
of FDI in the last decade, the main question revolves around the implication of a more favourable attitude of national governments towards inbound investment on their economies insofar as competitiveness is concerned (DUNNING, 1994)

Since national boundaries no longer set limits to market expansion, firms tend to compete in a more open environment. For the incumbent firms relying on the protection of national policies, newly arrived investors definitely pose new challenges and intensify competition (TRAILL, 1998). It is widely recognized that both inbound and outbound FDI have been more intense within the group of industrialized countries, which share similar standards of consumption, income level, increasing market strength and technological development. The share of these countries as the primary source of outbound FDI flow and stock in the period 1990-1994 was 89,4\% and 79,4\%, respectively. Furthermore, only $10 \%$ of outward FDI went to developing countries (DUNNING; NARULA, 1996). Despite this low percentage, it has been increasing in the last five years, mainly as a result of economic reforms implemented in these countries, and of the growing search for new markets by large multinational companies. ${ }^{3}$

In the sectors of activity and their related potentials for further expansion, the prospect for consolidation of FDI is very much dependent on the likelihood of spillover and on seizing new opportunities for further investment, according to three main conditions.

1 - development of infrastructure adequate for the requirements of new entrant firms, which should include a national innovation system, coupled with complementary cooperation conditions with existing firms.

2 - consumption standard in terms of income level and cultural flexibility.

3 - economic policies and government strategy attractive to FDI.

The more persistent these conditions are, the higher the likelihood is of companies expanding their existing assets. Moreover, economic and political stability play an important role as a safety net for increasing

3 Dunning and Narula (1996) also point out that only a small number of developing countries have been targeted by FDI, basically from Latin America and Asia: China, India, Brazil, Colombia, the Philippines, Thailand, Mexico, Chile, Venezuela, Hong Kong, Malasia, Singapore and Taiwan. 
investment not only by new companies but also by foreign incumbent firms on a sequential basis. ${ }^{4}$

Although the food industry has followed the same trends as industry as a whole, there can still be differences, particularly for countries outside the triad. Generally speaking, in the complex trends towards a globalized food market, and its concentration in the developed world, FDI has been recognized as the driving force of market integration, where production and consumption patterns might converge. This can be illustrated by the fact that the main market of the top multinational food and drink companies is located within the group of industrialized countries.

Nevertheless, not only does consumption retain inherited cultural habits, but also structural features also raise high barriers to the integration of less developed countries in the world market. Besides the fact that the local trade, generally relying on local firms, prevails, a high level of income concentration drives food consumption to a position below the limit of Engel's law, as any increase in income causes a corresponding increase in the quantity of food consumed. There is a strong argument according to which culture exerts influence in consumer behavior, making it resistant to changes introduced by the outside world, as pointed out by Traill (1998). This however seems to be more relevant in developing and third world countries, where local market conditions are still stumbling blocks on the way to universalization of food production and consumption.

Therefore, although the trends observed among industrialized countries are more typical of a convergence in food production and consumption, there is a move towards integrating other countries into the path made by expansion of trade, especially in processed food, and FDI. Foreign production by MNEs has significantly surpassed their exports in the major developed countries.(TRAILL, 1998, p. 54). Furthermore, for the fifty leading US food manufacturers, the value of the sales of their affiliates in 1992-93, was 12 times that of the companies' exports (HENDERSON, et al. 1998).

To a certain extent, food production in host countries has been a result of strategies designed by MNEs to reduce uncertainties and close the gaps between the production process and final consumption. If, on the one hand, FDI reflects the strategies of MNEs to strengthen position in a world competitive market, on the other hand it has ended up being conducive to a

4 According to Dunning (1994) $90 \%$ of MNEs activity is carried out from existing assets. To a large extent, a high proportion of sequential investment reflects the attractiveness of host countries, according to the conditions listed above. However, as far as developing countries are concerned, a considerable volume of investment in recent years consists of new entrants. 
strong process of concentration, by means of mergers and takeovers. (THE ECONOMIST, 1993)

Not all FDI is directed towards creating production capacity exclusively controlled by foreign affiliates. There are also significant arrangements through joint ventures, licensing, etc. The closer food consumption becomes to the international prevailing standards, the more widespread are initiatives to establish franchising and other forms of licensing, mostly in the retail segment. In fact, the expansion of fast food chains in developing countries in the last decades indicates this phenomenon. For US firms, the most remarkable evolution during the 1990s, took place in retail food stores and eating and drinking places (HENDERSON et al., 1998). However, investment in processing plants has attracted most attention lately, owing to its impacts on domestic market structure and conditions of supply. This is to say, on the one hand, that retail food stores and eating places, like fast food chains, have been at the core of market changes, as local firms are always prepared to adapt to the new ways food is bought and eaten. On the other hand, new entrant firms in the manufacturing sector account for a rise in the existing pattern of concentration and for the introduction of innovation, both organizational and technological.

\section{INTERNATIONAL TRADE AND FDI IN THE BRAZILIAN AGROINDUSTRY}

In the last decade, Brazilian trade policy has been affected by unilateral decisions taken by the government to open up the economy to foreign trade and investment (FLORES JR., 1998). This approach represents a radical change from an inward looking policy of import substitution and export promotion to a more liberalized economy. Tariff reductions on imports and subsidies on exports, in the context of the 1994 plan of stabilization, in which the overvaluation of the national currency played a key role. Furthermore, on the basis of mounting inbound investment in different sectors of activity, domestic industry can be seen to have started changing hands as foreign competition through new investments reached unprecedented levels, as is analyzed later in this article.

Although the full impact of this change in the Brazilian economy is still to be assessed as far as foreign trade is concerned, three outcomes can be detected. Firstly, despite an increase in exports, the trade balance has shown a persistent deficit in the last five years, mainly as a result of increasing 
imports. Within this context, trade policy, coupled with a welcoming approach to FDI, became the most important mechanism to boost competitiveness, replacing the previous strategy of domestic industrialization. Secondly, Brazilian exports have been diversified towards manufactured and semi processed products following the concern of firms about the retention of a larger share of added value as a crucial strategy to remain in business, particularly in the sectors related to processing agricultural products. Although Brazil's industrial sector is modern and well developed, all those sectors directly or indirectly connected to agriculture still account for around $40 \%$ of the country's total exports.

As a result, a great effort has been made to combine increasing productivity, decreasing costs, and innovation through product differentiation. This combination has been the outcome of a transformation taking place in Brazilian agroindustry in the last twenty years, when it moved from a position of producing mainly unprocessed products to investing more in manufactured ones. However, as will be shown below, this transformation towards a more sophisticated production has been markedly attached to the evolution of the domestic market. No significant change on the external front has occurred, by increasing the exports of processed products instead of commodities.

Thirdly, despite taking part in the regional common market MERCOSUR - Brazil still maintains a major trade relation with the E.U. and the USA. For the agroindustrial sectors, exports of unprocessed products were mainly destined to the EU (49,6\%) and Asia (21,2\%), in 1996. The processed commodities, mostly related to agriculture, were destined mainly for Asia (32,6\%) the EU (22,3\%) and the USA (21,7\%) (MICT/SECEX, 1998).

On the other hand, in the 1990s, when the Brazilian economy became more exposed to the world market, exports by agroindustry increased more than did the whole of the commodities. The most remarkable change occurred in the Basic Manufactures ${ }^{5}$ segment, whose exports increased by $168 \%$, followed by those of Food and Live Animals, which increased by $151.5 \%$ from 1980 to 1995 . In order to assess the relationship between agroindustry and the international market, two measures will be used here. Based on Balassa (1965) Revealed Comparative Advantage ${ }^{6}$ was calculated to highlight the weight of the agricultural sector as a total production and food production in particular in Brazilian external trade relations.

5 This includes leather, rubber, wood, paper, textile, etc.).

6 Although some criticism of this concept has been expressed by M. Lagnevik and E. Pitts, it can still be used as an indicator of trade performance in a particular industry. 


\section{$\mathrm{RCA}=\mathrm{XiJ} / \mathrm{XnJ} / \mathrm{XiT} / \mathrm{XnT} .100$}

where:

$\mathrm{XiJ}=$ value of exports of commodity i (Agricultural Products and Food and Animals) from a specific country (Brazil)

$\mathrm{XnJ}=$ value of world exports of commodity ( Agricultural Products and Food and Animals)

(Brazil)

$\mathrm{XiT}=$ value of exports of all commodities by a specific country

XnT $=$ value of world exports of all commodities (BALASSA, 1989)

Besides the expressive level of the comparative advantage of both segments, food shows a far higher performance, mostly related to semi processed products, as shown in table 1. It is also worth pointing out the increase of the index, more precisely when the economy became more open to foreign markets. Therefore, the Brazilian economy revealed its competitiveness in a sector dominated by homogenous products like feeding stuffs and coffee, which still account for the bulk of food exports, as can be seen by the trade balance of individual product segment in table 2. In fact, the majority of agricultural imports is accounted for by processed products, mainly cereals and preparations and dairy products. Moreover, more than $50 \%$ of cereals and preparations imports is of prepared breakfast food, a phenomenon of the last ten years, bearing in mind that in the late 1980s it was insignificant. Although the food industry shows persistent positive trade balance, basically as a result of commodity exports in the period 1991/ 96, those sectors where processing activity prevails - Dairy and Cereals Preparations - indicate the opposite. There is, furthermore, a significant disconnection in export/import relations, since the bulk of Brazilian exports consist of commodity or homogenous products, whereas imports are mostly processed products.

On the other hand, as agroindustry becomes more complex an increase in intra-industry trade is expected, following the development observed in industrialized countries, like the USA and the EU. The Brazilian agrofood industry, however, appears to be involved in trade of an interindustrial nature, as the most significant items of exports are feeding stuffs, coffee, sugar, fruit and meat, whose competitiveness is highly associated with comparative advantages, typically defined by economies of scale and 
cost reductions. According to the evidence shown in table 3 , the food industry, basically its commodity segments, has been responsible for a significant share of Brazilian exports, mitigating the overall downturn in the country's performance in external trade. Conversely, in those segments whose production is more sophisticated, like dairy and cereals preparations, the performance has been different. This discrepancy can also be detected in Table III, where it is possible to measure the importance of each segment of the Food Industry in both exports and imports.

Those segments whose final product is closer to the consumer, like cereals and preparations and dairy products, are significant in terms of food imports and show a persistent trade deficit in the period (see table 3 ). There is thus, a clear complementarity in the food trade between sub-sectors where product differentiation prevails and those where bulky commodities are the main feature.

The first implication of the evidence shown above is that, although the food industry has a high level of Revealed Comparative Advantage, its share of international trade is accounted for by segments whose production is not so sophisticated. The challenge to the national food industry is therefore different from that facing foreign industry interested in exporting to Brazil.

An exception to this scenario could develop within the context of MERCOSUR, where the Brazilian food industry could retain some degree of competitiveness. This does not necessarily apply to trade relations with Argentina, whose balance with Brazil has been in favor of the former, including the food sector.

Therefore, the path to competitiveness in the Brazilian agrofood industry seems to be still that of specialization, and of drifting away from the mainstream of international market depicted above. Processing industries in this sector are, consequently, strongly sensitive to aspects related to transaction costs like transportation, storage, tariffs, etc. Investment volume, economies of scale and control over sources of raw material also play an important role in decision making by firms.

On the other hand, it is in the domestic market that competition based on product differentiation has taken place. Two events have contributed to making this process more intense. Firstly, consumption has moved away from undifferentiated products, converging thus on the international standard. ${ }^{7}$ The strong influence of the food industry through marketing and product innovation has contributed decisively to making the

7 It has been noticeable the consumption of ready cooked meals, alongside 
domestic market attractive to new investment in product differentiation. On the other hand, in the last few years, food consumption has increased significantly as a result of the low rates of inflation produced by the stabilization plan, which have unleashed a repressed demand for basic food from previous years.

The main trends in the Brazilian food market are thoroughly in line with the international changes of recent years, despite a widespread informal network still surviving across the food production and consumption system. The fact that food intake increased significantly after the 1994's Real Plan caused a rise in real income, bringing large groups of the population closer to the main stream of the food market. Products like yogurt, hitherto out of the reach of most Brazilians, had its consumption increased by $193 \%$ between 1994 and 1997 (CASTRO, 1998). There is thus a prospect that, at the present standard of consumption, increases in the income will produce a corresponding rise in food intake, which should provide an incentive to attract investment.

Furthermore, coupled with a higher level of concentration, ${ }^{8}$ there has been a strong move towards the acquisition of national firms by foreign investment, mostly in a sequential fashion. The implementation of the Real Plan, not only made the Brazilian economy more attractive to foreign investors but also stimulated existing MNEs to expand their assets. This is shown both by acquisition and also upgrading of their technological performance. Companies like Nestle, Parmalat, Louis Dreyfus, Nabisco and Phillip Morris are leaders in this process. Nestle incorporated Tostines, a large national company producing biscuits, pasta and sweets. Unilever bought CICA, also large traditional company, from the tomato industry. Dreyfus acquired an orange juice plant from Frutesp, and Parmalat, beside investing in the pasta, biscuit and fruit juice sectors, incorporating more than twelve dairy plants throughout the country (Gazeta Mercantil, 1994).

The combination of international global trends and national events in Brazil after 1994 prompted this steady process whereby more than thirty medium sized and large national companies were sold to multinational corporations (CASTRO, 1998). Other evidence reinforces this fundamental change by the growing importance of FDI, all over Latin America. (The Economist, 1993). It should be added, however that, besides domestic factors,

the expansion of fast food chains, and other major changes similar to industrilized countries' food market.

8 The most striking cases are the meat and dairy sectors, in which the share of the value produced by the three main companies amounted to $64.3 \%$ and $80.7 \%$, respectively (CASTRO, 1998). 
the deepening of integration within MERCOSUR has a major influence on multinational decision making strategy. Notwithstanding the growing importance of FDI, the question remaining on whether the attractiveness of the domestic market plus the prospects of MERCOSUR is strong enough to enable the Brazilian agrofood system to grow out of commodity production and create competitive advantages by differentiating products.

However this question is something depending on the strategies of firms, and most importantly, their ability to keep pace with the ongoing changes in the domestic market. However, the main concern among those investigating this question in Brazil is related to structural systemic aspects, such as financing problems, agricultural productivity, articulation between segments of the food chain, quality of infrastructure, consistency of State industrial policy. These are aspects whose impacts are most likely to cause cost reduction and economy of scale, more crucially in commodity production. This might contribute to improve the position of agroindustry in the international market, where revealed comparative advantages are higher. Since the domestic market is too complex, the majority of the population still being susceptible to price reduction, the implication of cost reduction may be positive if the overall price relation in the economy does not change. As for the foreign market, the challenges reside not only in the quality of the raw material and the efficacy of the infrastructure, but also in strategies of companies to make their products more attractive. To what extent MNEs incoming investment will make this feasible for the Brazilian agrofood industry is still to be investigated.

\section{CONCLUSIONS}

In the context of globalization, individual countries have become involved in the world markets by adopting strategies to open their economies to foreign trade and direct investment. Simultaneously, firms have been forced into new competition in their own domestic market by imports and incoming investments. By and large, in this environment, competitiveness at the level of firms has been redefined by the growing importance of process and product innovation coupled with economy of scale. Although this is a many-sided trend, in which specific industrial sectors show different behavior, expansion of world trade and FDI has increasingly been determined by intra-industry trade, which is to a large extent deep rooted in created advantages.

The experience of the Brazilian food industry in the last five years in is very illustrative of the type of challenge facing developing countries in 
the context depicted in this analysis. Despite the export of a wide range of industrial product, agriculture is still a major source of export, as such having provided a buffer to the persistent trade deficit to a large extent generated by the national currency overvaluation in 1994. Furthermore, even within agroindustry itself, commodity products have mostly been responsible for bringing in hard currency, whereas processed food has contributed to deterioration in trade relations. Therefore, as indicated by the Revealed Comparative Advantages index, the Brazilian food industry still faces some difficulties in competing in the international market, where differentiated products are predominant. Much effort has yet to be made by governments but mainly by entrepreneurs to reverse the tide in such a way as to bring the country to a position where it can compete in the main foreign markets.

As far as FDI is concerned, the main question to be dealt with is the impact caused by foreign competitors on the overall performance of the different Brazilian economic sectors. A more accurate assessment is yet to be made of the implications of FDI, more particularly given the absence of an effective competition policy in the country. Thus the real benefits to the economy as a whole of foreign investors require further investigation.

To some extent, the situation of the Brazilian international trade of the food industry reveals the challenge facing many developing countries, for which commodities are still the most important export items. Moreover, the recent slump in prices of various commodities, following the crisis in Asia and Russia, contributes to an increasing of the obstacles to be overcome by developing countries.

\title{
RESUMO
}

\begin{abstract}
A globalização da economia mundial vem sendo amplamente discutida, revolvendo um debate tanto teórico quanto ideológico a respeito dessa multifacetada transformação, com a qual todos os países vem se envolvendo. Independente dos rumos dessa discussão, a questão da competitividade tem se tornado essencial nas relações econômicas internacionais da última década, quando a maioria dos países começaram a promover uma abertura tanto aos fluxos de investimento quanto de comércio.
\end{abstract}

Palavras-chave: comércio internacional, sistema agroalimentar brasileiro, competitividade. 


\begin{abstract}
Globalization has been deeply discussed revolving around a theoretical and ideological contention concerning this many-sided transformation with which, in one way or another, all countries have become entangled. Whatever the course of the discussion, competitiveness has become the key question in the international economic relations of the last decade, when most countries started opening up their economies to the external flows of trade and investment. The core of this analysis indicates the challenges facing Brazil in the international market when differentiated products appear to dominate trade relation. The discussion explores the extent to which foreign direct investment can change the conditions under which the country can boost its international competitiveness. As it will be argued here, the process of opening up the Brazilian economy in the 1990s has so far only consolidated the country's position as a commodity exporter, whereas the mainstream of the international market has consisted of processed and differentiated products.

Key-words: international trade, Brazilian agrofood system, competitiveness.
\end{abstract}

\title{
REFERENCES
}

BALASSA, B. 1965. Trade Liberalization and 'Revealed Comparative Advantage'. Manchester School, n. 33, p. 99-123, 1965.

BANNISTER, G. et al.Transnational corporations, the neo-liberal agenda and regional integration: establishing a policy framework. The Quartely Review of Economics and Finance, v. 34, p. 77-99, Summer 1994. Special Issue.

BRASIL atrai investimentos estrangeiros. Gazeta Mercantil, 12 de set. 1994. Relatório Agrobusiness.

CASTRO, A. C. Tendências do agribusiness brasileiro e o papel do sistema de transportes intermodal. Rio de Janeiro. Capes/Mare/CNPq/Finep-CPDA/UFRJ, 1998.

CHUDNOVSKI, D.; PORTA, F. La competitividad internacional: principales cuestiones conceptuales y metodologicas [S. 1.]: Universidad de la República, 1990. p. 71.

DUNNING, J. 1994. Reevaluating the benefits of foreign direct investment. Discussion Paper 188. International Investment and Business Studies, Department of Economics, University of Reading, v. 7, 1994. Series B.

DUNNING, J.; NARULA.. Developing Countries versus Multinational in a Globalizing world: the dangers of falling behind. Discussion Paper International Investment and 
Business Studies, Department of Economics, University of Reading, 1996.

FAO. Trade yearbook. Various issues.

FEKETEKUTY, G. The New Trade Agenda. OECD Occasional Paper, Group of Thirty, Washington, DC, n. 40, 1992.

FLORES JR., R. G. Brazilian trade policy and the WTO 1996 review. In: ARNDT, S.; MILNER, C. The world economy global trade policy 1997. [S. 1.: s. n.], 1998. p. 99-117.

HENDERSON, D. R. et al. International commerce in processed foods: patterns and curiosities. In; PICK, D. H. et al. (Ed.). Global Markets for processed foods: theoretical and practical issues. Westview: Westview Press, 1998.

HOEKMAN, B. M.; KOSTECKI, M. M. The political economy of the world trading system: from GATT to WTO. New York: Oxford University Press, 1996.

HOW to merge. The Economist, Jan. 1999.

JOSLING, T. Agriculture, global Trade liberalization and the process of regional integration. In: QUESTÕES AGROALIMENTARES E EXPERIÊNCIA DE INTEGRAÇÃO REGIONAL E SUB-REGIONAL DEPOIS DA RODADA URUGUAI DO GATT: UNIÃO EUROPÉIA, MERCOSUL E NAFTA: CONFRONTO DE EXPERIENCIAS, 1995, Rio de Janeiro. Anais... Rio de Janeiro: [s. n.], 1995.

KRUGMAN, P. Internationalismo Pop. Rio de Janeiro: Campus, 1997.

LIPSEY, R. G. 1997. Globalization and national government policies: an economist's view, In: DUNNING, J. Governments, globalization and international business New York: Oxford University Press, 1997.

LOW, P. et al. Does globalization cause a higher concentration of international trade and investment flows? WTO Working Paper, n. 8, 1998.

MACDONALD, B. The world trading system: the Uruguay Round and beyond. [S. 1.]: Macmillan Press Ltd, 1998.

MICT/SECEX. Balança Comercial Brasileira. 〈http://161.148.1.101/iprod12j.htm> Acesso em: 1998.

OSTRY, S. 1997. Globalization, Domestic Policies and the need for Harmonization. In: WAVERMAN, L. W. S. C.; GOTO, A. (Ed.). Competition policy in the global economy: modalities for cooperation. Lindon: Routledge, 1997.

REINERT, E. S. Competitiveness and its predecessors - a 500 year cross national perspective. Structural Change and Economic Dynamics, p. 23-42, 1995.

RUGMAN, A. M. Foreign direct investment and internalization in processed foods. In: PICK, D. H. et al. (Ed.). Global Markets for processed foods: theoretical and practical issues. Westeview: Westview Press, 1997.

STRANGE, S. An International Political Economy perspective. In: DUNNING, J. (Ed.). Governments, globalization and international business. New York: Oxford University Press, 1997. p. 132-145.

SURVEY, the food industry. The Economist, Dec. 1993.

TRAILL, W. B. Structural Changes in the European food industry: consequences for competitiveness. In: TRAILL, B. W.; PITTS, E. Competitiveness in the food industry. 
[S. 1.]: Blackie Academic \& Professional, 1998. p. 35-57.

VALDES, A. Agriculture in the Uruguay Round: interests of developing countries. World Bank Economic Review, v. 1, n. 4, p. 571-593, 1987.

WINKELMANN, M.; PITTS, A.; MATTHEWS, A. Revealed comparative advantage in the European food industry. Structural Change in the European Food Industries. (Discussion paper n. 6).

\section{ANEXOS}

Table 1 - BRAZIL'S REVEALED COMPARATIVE ADVANTAGE OF AGRICULTURAL PRODUCTS FOOD AND ANIMALS EXPORTS

$\begin{array}{ccc}\text { Year } & \text { Agric. Products } & \text { Food and Animals } \\ 1991 & 268 & 300 \\ 1992 & 266 & 290 \\ 1993 & 278 & 306 \\ 1994 & 318 & 343 \\ 1995 & 333 & 367 \\ 1996 & 344 & 378\end{array}$

SOURCE: FAO, Trade Yearbook.

Table 2 - TRADE BALANCE OF TOTAL MERCHANDISE, AGRICULTURAL SECTOR AND SUBSECTORS OF FOOD INDUSTRY, IN US $\$ 10.000$

\begin{tabular}{|c|c|c|c|c|c|c|}
\hline Subsectors & $\begin{array}{c}19 \\
91 \\
\end{array}$ & $\begin{array}{c}19 \\
92 \\
\end{array}$ & $\begin{array}{c}19 \\
93 \\
\end{array}$ & $\begin{array}{c}19 \\
94 \\
\end{array}$ & $\begin{array}{l}19 \\
95 \\
\end{array}$ & $\begin{array}{l}19 \\
96 \\
\end{array}$ \\
\hline Meat and meat prep. & $\begin{array}{c}75 \\
772 \\
\end{array}$ & $\begin{array}{c}10 \\
8912 \\
\end{array}$ & $\begin{array}{c}12 \\
7881 \\
\end{array}$ & $\begin{array}{c}11 \\
8749 \\
\end{array}$ & $\begin{array}{r}10 \\
6419 \\
\end{array}$ & $\begin{array}{r}12 \\
8722 \\
\end{array}$ \\
\hline Dairy prod. and eggs & 21831 & 6265 & 13163 & 26642 & 63869 & 49549 \\
\hline Cereals and prep. & 124205 & 101457 & 136117 & 156743 & 186769 & 206401 \\
\hline Fruit and veget. & $\begin{array}{c}78 \\
845 \\
\end{array}$ & $\begin{array}{c}11 \\
3623 \\
\end{array}$ & $\begin{array}{c}86 \\
288 \\
\end{array}$ & $\begin{array}{c}71 \\
999 \\
\end{array}$ & $\begin{array}{r}48 \\
647 \\
\end{array}$ & $\begin{array}{r}94 \\
504\end{array}$ \\
\hline Sugar and honey & $\begin{array}{c}47 \\
799 \\
\end{array}$ & $\begin{array}{c}63 \\
668 \\
\end{array}$ & \begin{tabular}{|c|}
85 \\
160 \\
\end{tabular} & $\begin{array}{c}10 \\
4025 \\
\end{array}$ & $\begin{array}{r}19 \\
4051 \\
\end{array}$ & $\begin{array}{r}16 \\
1963 \\
\end{array}$ \\
\hline Coffee, tea, coc. sp. & $\begin{array}{c}18 \\
9301\end{array}$ & $\begin{array}{c}14 \\
9025 \\
\end{array}$ & $\begin{array}{c}16 \\
7402 \\
\end{array}$ & $\begin{array}{c}29 \\
7819 \\
\end{array}$ & $\begin{array}{r}25 \\
7661 \\
\end{array}$ & $\begin{array}{r}23 \\
1900 \\
\end{array}$ \\
\hline Feeding stuffs & $\begin{array}{c}15 \\
0550 \\
\end{array}$ & $\begin{array}{c}17 \\
6000 \\
\end{array}$ & $\begin{array}{c}19 \\
8068 \\
\end{array}$ & $\begin{array}{c}21 \\
3301 \\
\end{array}$ & $\begin{array}{r}21 \\
4556 \\
\end{array}$ & $\begin{array}{r}28 \\
6870 \\
\end{array}$ \\
\hline Miscellaneous & $\begin{array}{r}66 \\
5 \\
\end{array}$ & $\begin{array}{c}13 \\
95 \\
\end{array}$ & $\begin{array}{r}12 \\
3 \\
\end{array}$ & $\begin{array}{r}- \\
1345 \\
\end{array}$ & $\begin{array}{r}- \\
9687\end{array}$ & $\begin{array}{r}- \\
8935\end{array}$ \\
\hline FOOD AND ANIMALS & $\begin{array}{c}39 \\
3596 \\
\end{array}$ & $\begin{array}{c}50 \\
3257 \\
\end{array}$ & $\begin{array}{c}51 \\
2337\end{array}$ & $\begin{array}{c}60 \\
9345 \\
\end{array}$ & $\begin{array}{r}54 \\
6056 \\
\end{array}$ & $\begin{array}{r}63 \\
3310 \\
\end{array}$ \\
\hline AGRICULTURAL PROD. & $\begin{array}{c}51 \\
9793\end{array}$ & $\begin{array}{c}66 \\
9081\end{array}$ & $\begin{array}{c}63 \\
7053\end{array}$ & $\begin{array}{c}81 \\
2144\end{array}$ & $\begin{array}{r}71 \\
1658\end{array}$ & $\begin{array}{r}80 \\
2724\end{array}$ \\
\hline TOTAL MERCHANDISE TRADE & $\begin{array}{r}86 \\
4360 \\
\end{array}$ & $\begin{array}{c}13 \\
44670\end{array}$ & $\begin{array}{c}11 \\
07160\end{array}$ & $\begin{array}{c}80 \\
3330\end{array}$ & $727700^{-}$ & 918500 \\
\hline
\end{tabular}

SOURCE: FAO, Trade Yearbook. 
Table 3 - SHARE OF EXPORTS AND IMPORTS BY SEGMENTS OF FOOD INDUSTRY IN \%

\begin{tabular}{|c|c|c|c|c|c|c|c|c|c|c|c|c|}
\hline \multirow{2}{*}{$\begin{array}{l}\text { YEAR } \\
\text { Food sector }\end{array}$} & \multicolumn{2}{|l|}{1991} & \multicolumn{2}{|l|}{1992} & \multicolumn{2}{|l|}{1993} & \multicolumn{2}{|l|}{1994} & \multicolumn{2}{|l|}{1995} & \multicolumn{2}{|l|}{1996} \\
\hline & $\exp$ & imp & Exp & imp & $\exp$ & imp & $\exp$ & imp & Exp & imp & $\exp$ & imp \\
\hline Meat and prepar & 11.2 & 4.8 & 13.4 & 5.6 & 13.7 & 1.6 & 10.6 & 3.3 & 9.7 & 3.7 & 10.5 & 3.4 \\
\hline Dairy products & 0.1 & 8.1 & 0.2 & 3.3 & 0.3 & 4.8 & 0.0 & 6.1 & 0.1 & 10.4 & 0.2 & 8.2 \\
\hline Cereals and prep. & 0.1 & 45.3 & 0.2 & 43.0 & 0.3 & 41.8 & 0.2 & 36.1 & 0.3 & 30.6 & 0.8 & 34.7 \\
\hline Fruit and veg. & 15.1 & 14.9 & 15.9 & 13.0 & 12.7 & 11.2 & 10.9 & 14.6 & 11.1 & 16.0 & 12.8 & 14.0 \\
\hline Sugar and honey & 6.2 & 0.5 & 7.3 & 1.1 & 9.0 & 0.7 & 8.5 & 0.6 & 15.0 & 1.0 & 11.8 & 1.1 \\
\hline Coffee, tea, coc & 23.9 & 0.5 & 16.5 & 0.6 & 17.5 & 0.6 & 24.0 & 0.9 & 20.6 & 2.8 & 17.2 & 2.3 \\
\hline Feeding stuffs & 19.1 & 0.5 & 19.5 & 0.7 & 20.6 & 0.6 & 17.1 & 0.4 & 16.4 & 0.6 & 20.5 & 1.0 \\
\hline Miscellaneous & 0.2 & 0.5 & 0.3 & 0.6 & 0.4 & 1.0 & 0.4 & 1.3 & 0.3 & 2.2 & 0.3 & 2.2 \\
\hline FOOD AND ANI. & 76.0 & 76.5 & 73.6 & 69.1 & 74.7 & 63.7 & 71.9 & 66.1 & 73.5 & 69.8 & 74.1 & 68.0 \\
\hline TOTAL AGRIC. & 100 & 100 & 100 & 100 & 100 & 100 & 100 & 100 & 100 & 100 & 100 & 100 \\
\hline
\end{tabular}

SOURCE: FAO, Trade Yearbook. 